\title{
Phytotoxicity in Seedlings of Rhizophora mangle (L.) Exposed to 2,4-Dichlorophenoxyacetic Acid under Experimental Conditions
}

\author{
Carlos A. Chan-Keb ${ }^{1}{ }^{(D}$, Claudia M. Agraz-Hernández ${ }^{2, *}{ }^{\circledR}$, Román A. Pérez-Balan ${ }^{1}$, \\ Eduardo J. Gutiérrez-Alcántara ${ }^{1}$, Raquel Muñiz-Salazar ${ }^{3}$, Jordán E. Reyes-Castellano ${ }^{2}$ and Juan Osti-Sáenz ${ }^{2}$ \\ 1 Facultad de Ciencias Químico Biológicas, Universidad Autónoma de Campeche, Avenida Ing. Humberto \\ Lanz Cárdenas S/N, Colonia Ex Hacienda Kalá, San Francisco de Campeche 24085, Campeche, Mexico; \\ carachan@uacam.mx (C.A.C.-K.); roaperez@uacam.mx (R.A.P.-B.); ejgutier@uacam.mx (E.J.G.-A.) \\ 2 Instituto EPOMEX, Universidad Autónoma de Campeche, Av. Heroe de Nacozari \#480, Campus 6 de \\ Investigaciones, San Francisco de Campeche 24029, Campeche, Mexico; reyes_jordan@hotmail.com (J.E.R.-C.); \\ jostisaenz@gmail.com (J.O.-S.) \\ 3 Laboratorio de Epidemiología y Ecología Molecular, Escuela Ciencias de la Salud, Universidad Autónoma de \\ Baja California, Blvd. Zertuche y Blvd. De los Lagos s/n. Fracc. Valle Dorado, \\ Ensenada 22890, Baja California, Mexico; ramusal@uabc.edu.mx \\ * Correspondence: clmagraz@uacam.mx; Tel.: +52-981-8119800 (ext. 2010110)
}

Citation: Chan-Keb, C.A.;

Agraz-Hernández, C.M.; Pérez-Balan,

R.A.; Gutiérrez-Alcántara, E.J.;

Muñiz-Salazar, R.; Reyes-Castellano,

J.E.; Osti-Sáenz, J. Phytotoxicity in

Seedlings of Rhizophora mangle (L.)

Exposed to 2,4-Dichlorophenoxyacetic

Acid under Experimental Conditions.

J. Mar. Sci. Eng. 2021, 9, 1417.

https://doi.org/10.3390/jmse9121417

Received: 13 October 2021

Accepted: 7 December 2021

Published: 11 December 2021

Publisher's Note: MDPI stays neutral with regard to jurisdictional claims in published maps and institutional affiliations.

Copyright: (c) 2021 by the authors. Licensee MDPI, Basel, Switzerland. This article is an open access article distributed under the terms and conditions of the Creative Commons Attribution (CC BY) license (https:// creativecommons.org/licenses/by/ $4.0 /)$.

\begin{abstract}
Mangroves are considered one of the most productive ecosystems worldwide, providing multiple environmental goods and services; however, in recent years, there have been modifications and deterioration in the structure and function of these ecosystems, caused by various natural events and anthropic activities, such as the construction of roads, wastewater discharge, unsustainable livestock, and agricultural practices, as well as the impact of chemicals, such as heavy metals, oil spills, and the use of herbicides. In this research, phytotoxic effects on seedlings of Rhizophora mangle were evaluated at an exposure of five dilutions $\mathrm{w} / \mathrm{v}(5 \%, 10 \%, 25 \%, 50 \%$, and $100 \%)$ of the commercial presentation of 2,4-dichlorophenoxyacetic acid (2,4-D). Propagules grown in a greenhouse under local tidal regimes were used, so the growth of stem diameter, height, biomass production in root, leaves, and stems, as well as the concentration of chlorophyll $a$ of the exposed seedlings were measured. The comparison of these parameters in seedlings with only seawater presented significant differences $(p \leq 0.05)$ and inhibitory effects on growth (diameter), the stem concentration of chlorophyll $a$, and the production of biomass of leaves, stems, and roots. The inhibitory effect of exposure to 2,4-D on chlorophyll production and root biomass is highlighted, with an average decrease of $45 \%$ relative to the control. The sensitivity of the Rhizophora mangle seedlings to the applied concentrations of herbicide evidence the inhibitory effects on the morphological variables of biomass production and chlorophyll $a$ production in mangrove leaves.
\end{abstract}

Keywords: inhibitory effects; red mangrove; herbicide; morphological variables; chlorophyll

\section{Introduction}

Mangroves provide a wide variety of services, so they are considered one of the most productive ecosystems worldwide [1-3]. Mangroves act as important breeding grounds for a variety of species and protect shorelines from hurricane winds, waves, and floods. Mangroves also help prevent erosion by stabilizing sediments trough their root systems. They maintain water quality and clarity, filtering pollutants and trapping sediments originating from land [4]. Mangrove soils are highly effective carbon sinks, storing large quantities of carbon and stopping it from entering the atmosphere [5]. Mangroves cover approximately $13,776,000$ ha worldwide [6]. Over the past 50 years, approximately one-third of the world's mangrove forests have been destroyed due to constant threat by anthropogenic activities, such aquaculture, industry and coastal development, road construction, wastewater discharges, as well as unsustainable livestock and agricultural practices $[7,8]$. The 
impact of chemicals of anthropic origin, such as heavy metals, oil spills, and herbicides, on tropical and subtropical habitats can reduce the survival of seedlings and modify the hydrological, geochemical, and physicochemical conditions of interstitial waters; these effects have been shown in mangrove forests [9-11]. In this regard, refs. [12,13] describe the physicochemical parameters associated with changes to oxide-reduction conditions, temperature, salinity, and the $\mathrm{pH}$ of interstitial water. On the other hand, the productivity of mangrove ecosystems has been diminished or eliminated due to the deterioration and degradation caused by anthropic activities [14], such as the contributions of effluents with high concentrations of nutrients, pesticides, herbicides, and heavy metals, among others. Representing this type of effluent, a latent risk to the environmental services provided by mangrove ecosystems exists, through generating the effects of toxicity and an inhibition in growth, destabilizing different plant communities, including effects on species and even risks to human health $[15,16]$, which shows that this type of discharge affects the functions of plants, such as the capture of energy for biomass growth, photosynthesis, gas exchange, $\mathrm{CO}_{2}$ uptake, and the release of $\mathrm{O}_{2}$ and, therefore, the processes of nutrient recycling. The first studies performed on the effect of 2,4-D on mangroves were conducted by the authors of [17], where the first signs observed were withered leaves and subsequent defoliation of mangrove seedlings. In the natural environment, the concentration of herbicides that are discharged into mangrove forests is determined by several factors, such as the dose applied to an agricultural area and the dilution in soil through the effects of rain and tide [18]. It has also been described that mangrove species (Avicennia marina (Forssk) Vierh, Aegiceras corniculatum L.) that excrete salts from their stems and leaves are more tolerant to exposure to metals and herbicides, while species such as Rhizophora stylosa Griff and Ceriops australis (C.T. White) Ballmet, T.J.Sm. \& J.A.Stoddart, which are considered as mangrove plants that exclude sea salts from their tissues, are less tolerant to the pollutants mentioned $[10,19,20]$.

Despite this, there is little research evaluating the impact of pesticides on the morphology and physiology of mangrove species, as well as on the effects they may have on the primary productivity of these types of ecosystems. Therefore, the present study aims to determine the phytotoxic effects of exposure to the herbicide 2,4-dichlorophenoxyacetic acid (2,4-D) on the growth of stem diameter, height, biomass production in root, leaves, and stems, as well as the chlorophyll $a$ concentrations in seedlings of Rhizophora mangle L., under greenhouse conditions with local tidal regimes.

\section{Description of the Rhizophora mangle Hypocotyl Collection Area}

The collection of Rhizophora mangle hypocotyls was carried out in the Los Petenes Biosphere Reserve (RBLP), located in the Gulf of Mexico [21] (Figure 1), with an area of 282,857 ha [22].

The area has a warm and sub-humid climate, with a monthly average temperature of $26^{\circ} \mathrm{C}$ and an average annual rainfall of $819 \mathrm{~mm}$ [23]. The area has karst-type soils and hills, dominated by Solonchack, and, to a lesser extent, Gleysols and Histosols [24], which comprise a karst-tectonic land system, with a main morphological expression of plains, a geomorphological landscape of coastal marshes with large petenes and coastal marshes with blanquizales, as well as a degree of recent karst evolution [24]. The reserve is characterized by its intense dynamics with the sea, through underground drainage and tidal influence, by the settling of soil of organic origin with constant outcrops of the water table [25].

At the national and international levels, the RBLP is of great relevance as it is part of an ecoregion that involves the Ría Celestún Biosphere Reserve and the El Palmar due to their status of being protected natural areas in the state of Yucatán, and it is located in the Priority Regions of Mexico, under all categories of Priority Terrestrial Regions No. 145, Priority Marine Regions No. 60, Priority Hydrological Regions No. 102, and Areas of Importance for the Conservation of Birds-AICAS (AICA SE-28), and was declared in 2004 as RAMSAR site No. 1354 [22]. In addition to having unique ecosystems, such as sea grasses, petenes, and mangroves, it is considered to be the largest and most well-preserved 
in the entire country, mainly due to the latter ecosystem covering $70.3 \%$ of the total surface of the reserve [26].
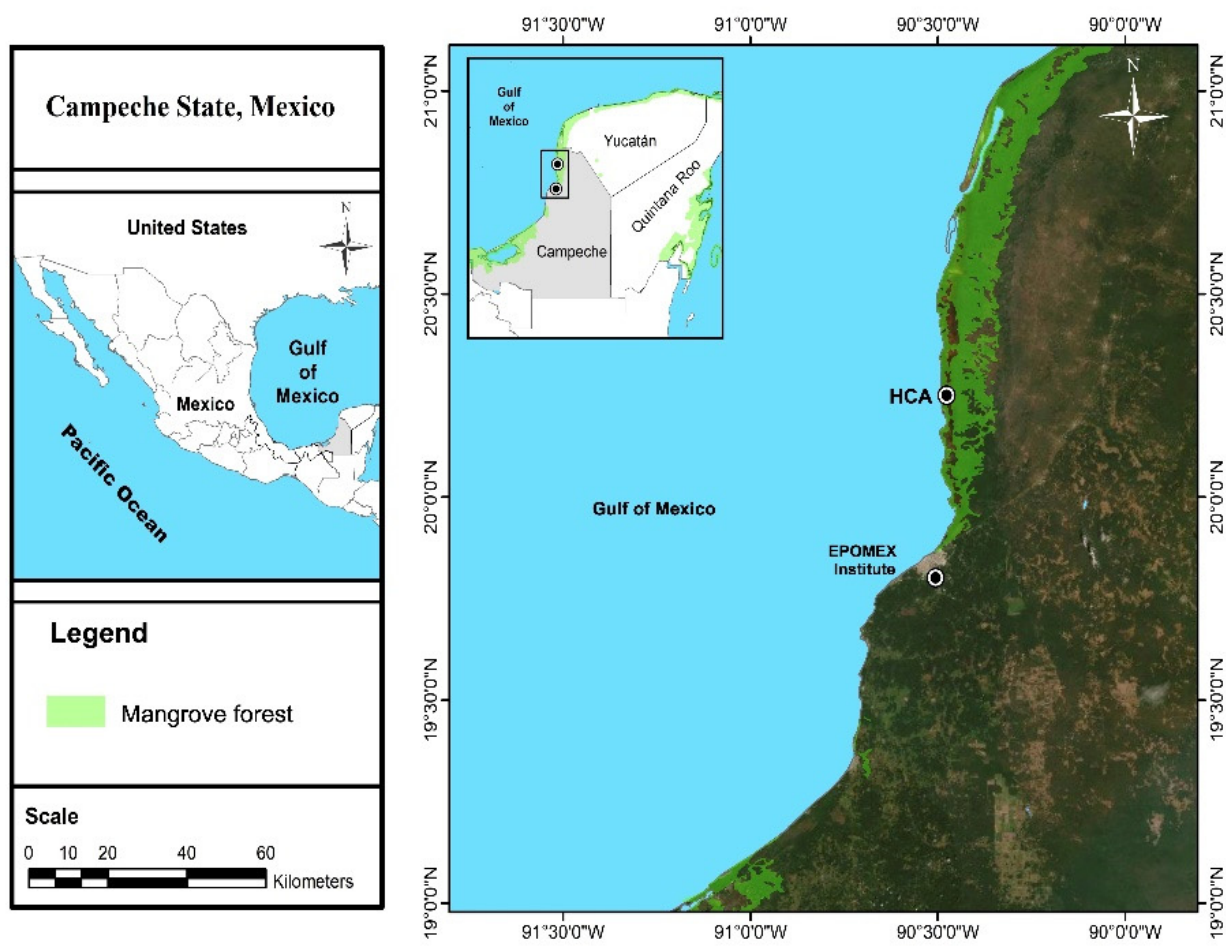

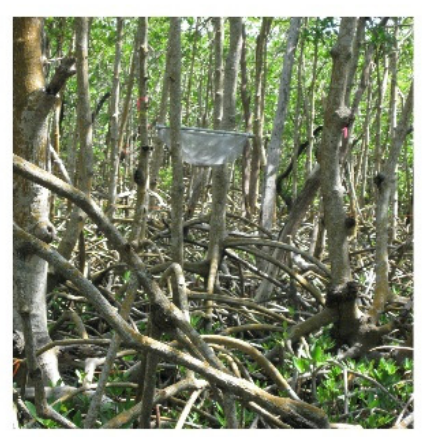

Hypocotyl collection area (HCA)

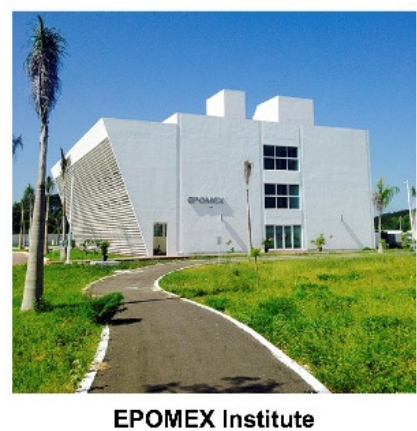

Figure 1. Geographic location of the Rhizophora mangle hypocotyl collection forest in the Los Petenes Biosphere Reserve (RBLP), Campeche, Mexico, and development sites of the experiment (EPOMEX Institute).

Four mangrove species are recorded in the RBLP, namely, Avicennia germinans L., Laguncularia racemosa (L.) C.F. Gaertn., Conocarpus erectus L., and Rhizophora mangle (Figure 1), the latter species dominating [27]. R. mangle develops in habitats with constant fresh water supply, along with influence and frequency of the tide, preferably in coastal environments with low wave energy [28]. It is dominant along the coastline, forming monospecific forests, while inland, it is common to find it associated with other species [29]. R. mangle has low tolerance to high concentrations and variations in salinity, as it does not have desalination glands nor does it accumulate salts in the vacuoles, and it only performs ultrafiltration processes to regulate the salt in the environment [29], with optimal developments between 8 and $26 \mathrm{~g} / \mathrm{kg}$ [30]. It is viviparous, produces propagules that germinate in the mother tree, and it has a wide dispersion due to the tide, birds, and crustaceans. The time of propagule formation is between 4 and 7 months [31]. It is characterized as reproducing all year, but with maximums during the rainy season [32].

Despite this, the northern area of the RBLP exhibits environmental deterioration due to human settlements in the urban area of the city of Campeche, due to the contributions of urban and agricultural wastewater $[27,33]$. Likewise, more than 6000 ha of dead mangroves were recorded in the central part of the reserve, adjacent to the island of Jaina, which was caused by the construction and expansion of communication routes, fires, and illegal logging, as well as an increase in the agricultural and livestock frontier [27].

\section{Materials and Methods}

\subsection{Construction and Environmental Stabilization of the System}

Twelve Rotoplas ${ }^{\circledR}$ tanks (Grupo Rotoplas S.A.B. de C.V., Mexico city. Mexico) made of linear low-density polyethylene material) with a $450 \mathrm{~L}$ capacity were built inside a $51.7 \mathrm{~m}^{2}$ greenhouse that was $2 \mathrm{~m}$ high. Hydraulic systems were individually fitted to each tank to facilitate the simulation of the local tidal regime: high tide from gravity and low tide 
through pumping (Figure 2). Shut-off valves and 3/4" horsepower pumps connected to PVC tubes were installed to control the speed and direction of the circulating water.

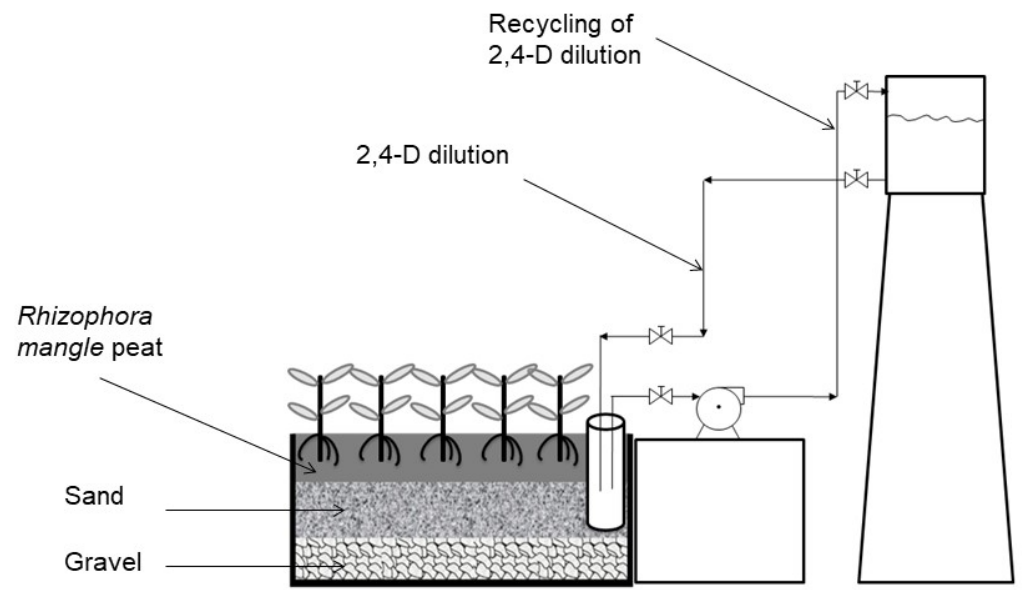

Figure 2. Diagram of the treatment system for exposure to 2,4-D with subsurface recirculation.

The temperature was fixed at $26 \pm 3{ }^{\circ} \mathrm{C}$, with two 12,000 BTU (English power units) air conditioner systems and ventilators. Light incidence was $\sim 50 \%$, reduced with a shadow mesh fixed at a certain height, which allowed air circulation and avoided the build-up of high temperatures inside the facilities. Filters in each tank were built from top to bottom with $0.16 \mathrm{~m}^{3}$ of mangrove peat, $0.13 \mathrm{~m}^{3}$ of sand, and $0.13 \mathrm{~m}^{3}$ of gravel. The mangrove peat was composed of $55 \%$ lime, $42 \%$ sand, and 3\% clay, which correspond to the soil texture category of silt loam with sand grains and a low content of clay. Other conditions, such as topography (ground leveling), frequency of flooding, as well as interstitial water salinity $(20 \pm 2 \mathrm{~g} / \mathrm{kg})$ and redox potential $(-195.9 \pm 84 \mathrm{mV}$, oxygenic environment) were set to simulate the plant collection site, following the historical records in [34]. Salinity adjustments were performed following the criteria in [35]. During a 50-day period, water parameters were monitored, and afforestation was performed, ensuring that the conditions were similar to the natural environment (Figure 3).

System buit-up and stabilization Afforrestation and
conditioning
2,4-D application

$(5,10,25,50$, and $100 \%)$
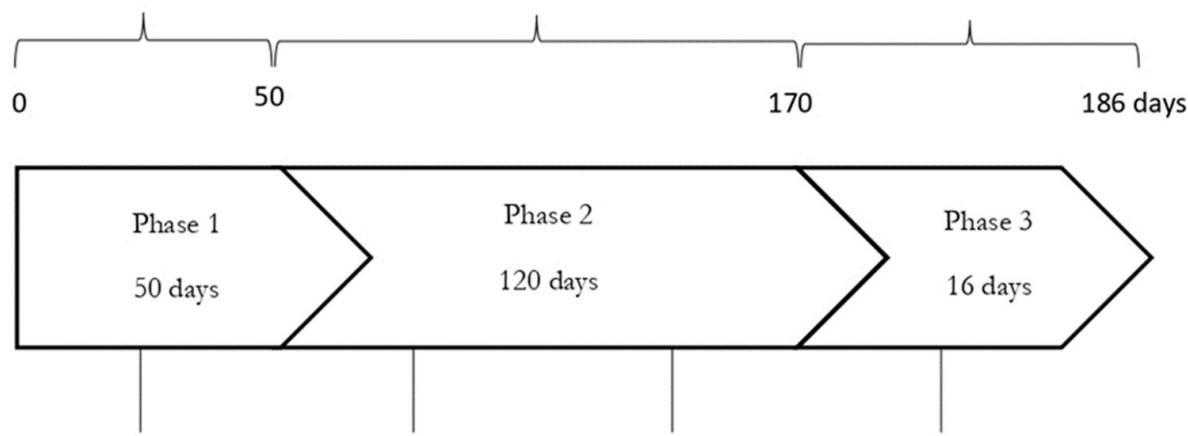

a) Water recirculation and homogenization

Radicular system of the intertitial development water and sediments.

b) Artificial tidal adjusments
First level leaves sprout And records of inter nodal growth. No mortality
Monitoring of growth, chlorophyll a, biomass, and physicochemical parameters of interstitial water

Figure 3. Experiment timeline events. 


\subsection{Stages of Reforestation and Conditioning}

Bioassay and sample analyses were performed at the EPOMEX Institute of the Autonomous University of Campeche, Mexico (Figure 1). The collection of Rhizophora mangle hypocotyls was carried out in September 2018, and collection and analyses of the samples were carried out in April 2019 during the development of the experiment (Phase 3, Figure 3).

R. mangle hypocotyls were collected from a monospecific forest located in the Los Petenes Biosphere Reserve $\left(19^{\circ} 57^{\prime} 26.108^{\prime \prime}\right.$ N- $90^{\circ} 26^{\prime} 59.40^{\prime \prime}$ W, Figure 1) in Campeche State, the Gulf of Mexico. Hypocotyls that showed suitable conditions were selected; any with signs of plague, drying, or damage were rejected. Hypocotyls were planted with a density of 65 per tank. The root system development and first sprout leaf were observed over a 120day period (Figure 3). During this stage, physicochemical data were collected and tested using one-way analysis of variance (one-way ANOVA) considering the data of individual tanks in comparison to each other. No significant differences were found ( $p>0.05$, Table 1$)$. Internodal growth was recorded from all tanks, and no plant mortality was detected at this stage. We assumed that homogeneous conditions were already set, which would prompt nutrient absorption by the plant seedlings, and they were ready for exposure to the 2,4-D (2,4-dichlorophenoxyacetic acid).

Table 1. Analysis of variance (ANOVA) of a pathway of the physicochemical parameters of the interstitial water in the ponds during the conditioning and afforestation phase of the seedlings of Rhizophora mangle $(p<0.05)$.

\begin{tabular}{cccc}
\hline Parameters & gl (Factor, Error) & Statistic $\mathbf{F}$ & $p$ Value \\
\hline Temperature $\left({ }^{\circ} \mathbf{C}\right)$ & $(11,84)$ & 0.09 & 0.990 \\
Potential redox $(\mathbf{m} \mathbf{V})$ & $(11,84)$ & 0.12 & 0.990 \\
Salinity $(\mathbf{g} / \mathbf{k g})$ & $(11,84)$ & 0.68 & 0.757 \\
pH & $(11,84)$ & 1.06 & 0.404 \\
\hline
\end{tabular}

\subsection{Application of 2,4-Dichlorophenoxyacetic (2,4-D)}

To determine the degree of phytotoxicity on Rhizophora mangle seedlings, we used a commercial presentation of 2,4-D called "Full-Mina" (Dow AgroSciences de Colombia S.A., Bogota. Colombia) and we considered the common practice of farmers for scattering pesticide, diluting an aliquot of $450 \mathrm{~mL}$ of pesticide bottle content $(480 \mathrm{~g} / \mathrm{L}$ concentration of active principle) with $20 \mathrm{~L}$ water in a container to fumigate; we assume this concentration as a $100 \%$ dilution $(10.8 \mathrm{~g} / \mathrm{L})$ to complete all the dilutions for this experiment. The active principle of 2,4-D used in this experiment (2,4-D dimethyl amine salt (DMA), case number: 2008-39-1) has an estimated half-life in an anaerobic aquatic laboratory between 41 and 333 days. 2,4-D has a solubility of 730,000 $\mathrm{mg} / \mathrm{L}$ at neutral $\mathrm{pH}$ and an octanol/water partition coefficient $\left(\log \mathrm{K}_{\mathrm{ow}}\right)$ of 0.177 , also at neutral $\mathrm{pH}$ [36].

Five treatments and a control (negative) were performed in duplicate for a total of 12 experimental units (UE). Then, 5 different dilutions of 2,4-D were carried out with seawater at weight/volume concentrations of $5 \%, 10 \%, 25 \%, 50 \%$, and $100 \%,(0.54,1.08$, $2.7,5.4$, and $10.8 \mathrm{~g} / \mathrm{L}$, respectively).

During the application stage of 2,4-D to generate the different concentrations of exposure for the plants contained in each experimental unit, the monitoring of the physicochemical parameters was carried out every 4 days.

\subsection{Effects on Chlorophyll Growth and Production}

\subsubsection{Effects on Growth in the Seedlings of Rhizophora mangle}

The growth response of seedlings was recorded at 12 and 16 days after exposure to 2,4-D. Ten seedlings were randomly selected from each tank and measured with the help of a Vernier (digital accuracy of $0.02 \mathrm{~mm}$ ) that measured internodal distance, stem diameter, and total height [37]. At the end of the experiment, three plants were extracted from each 
tank to measure the total biomass production. The stem, leaves, and roots of these plants were dehydrated at $60{ }^{\circ} \mathrm{C}$ in a convection furnace for three days [38].

\subsubsection{Chlorophyll Concentration}

The determination of the concentration of chlorophyll $a$ was carried out by collecting fresh leaves from three mangrove seedlings in each EU. First, $2 \mathrm{~g}$ of fresh leaf was weighed and deposited into $15 \mathrm{~mL}$ test tubes, then crushed, and $10 \mathrm{~mL}$ of acetone at $90 \%(v / v)$ was added, stirred, and left to rest in the dark at $4{ }^{\circ} \mathrm{C}$ for $24 \mathrm{~h}$, then taken to room temperature and centrifuged at $2700 \mathrm{rpm}$ for $5 \mathrm{~min}$. Subsequently, the supernatant of each sample the absorbances was measured using a spectrophotometer 6500 (JENWAY Stafford. United Kingdom) at wavelengths of $665 \mathrm{~nm}, 645 \mathrm{~nm}$, and $630 \mathrm{~nm}$. Ninety-percent acetone was used as a target. The concentration of chlorophyll was determined based on the equation provided in [39]. The results for the chlorophyll $a$ concentration in $\mathrm{mg} / \mathrm{L}$ were adjusted per gram of tissue by fresh weight.

$$
\text { Chlorophyll } a(\mathrm{mg} / \mathrm{L})=11.6 \times(\text { Abs. 665) }-1.31 \times(\text { Abs. 645 })-0.14 \times(\text { Abs. 630 })
$$

where Abs. is the absorbance of the respective wavelengths.

\subsection{Statistical Analysis}

Physicochemical parameters of interstitial water (salinity, redox potential, temperature) and the morphological variables (height and diameter) were analyzed using a one-way ANOVA that was applied to validate the homogeneous conditions of the biological variables and the physicochemical parameters before the application of 2,4-D (conditioning phase of the experiment). To assess the toxicity effect of 2,4-D, morphological variables and chlorophyll $a$ concentrations in Rhizophora mangle seedlings were compared between treatments and exposure time, using two-way ANOVA. At the end of the experiment, the production of biomass from the mangrove seedlings (root, leaves, and stem) was also compared by applying one-way ANOVA. After this analysis, a post hoc test was applied using Fisher's least significant difference (LSD) method, with a significance level of $\alpha=0.05$. Before the comparison analyses, the normality of the variables was validated using the method from [40], with a level of significance of $\alpha=0.05$; not complying with the assumption of normal distribution, the data were transformed using the Box-Cox method so that the variables would present the assumptions of a normal distribution [41]. Finally, simple linear regression analysis was performed, establishing 2,4-D as an independent variable the concentration and chlorophyll $a$ as a dependent variable. The total biomass of the seedlings was also a dependent variable. All statistical analyses were performed using STATISTICA V.12 (CCopyright StatSoft, Inc., Palo Alto, CA, USA, 1984-2014) and SPSS 15.0 software (Copyright (C) 2006 of SPSS Inc., Chicago, IL, USA) for Windows [41].

\section{Results}

\subsection{Physicochemical Parameters before and during the Application of the Herbicide}

During the conditioning and afforestation phase of the seedlings (Figure 2, 120 days), there was no significant variation in the physicochemical parameters of the interstitial water (Table $1, p>0.05)$. The interstitial water remained slightly alkaline (7.4 \pm 0.2$)$ and lexical $(142 \pm 16 \mathrm{mV})$; the temperatures were in the range of $23 \pm 2{ }^{\circ} \mathrm{C}$. The survival of seedlings during this phase was $100 \%$.

The physicochemical conditions of the interstitial water in the control units and those treated with the agrochemical 2,4-D showed a neutral $\mathrm{pH}$ with a slight tendency to alkalinity $(7.2 \pm 0.1$ to $7.6 \pm 0.3)$ and temperatures in the range of $29.0 \pm 0.5$ to $30 \pm 1{ }^{\circ} \mathrm{C}$. The redox potential of the interstitial water was heterogeneous and anoxic (156 \pm 25 to $-147 \pm 142 \mathrm{mV}$ ), with significant differences between treatments (Table 2, $p<0.05$ ). 
Table 2. ANOVA of a pathway of the physicochemical parameters of interstitial water in ponds during treatment with 2,4-D acid in seedlings of Rhizophora mangle $(p<0.05)$.

\begin{tabular}{cccc}
\hline Parameters & gl (Factor, Error) & Statistic F & $p$ Value \\
\hline Temperature $\left({ }^{\circ} \mathbf{C}\right)$ & $(5,18)$ & 0.22 & 0.940 \\
Potential redox $(\mathbf{m} \mathbf{V})$ & $(5,18)$ & 4.99 & 0.005 \\
Salinity $(\mathbf{g} / \mathbf{k g})$ & $(5,18)$ & 0.77 & 0.580 \\
pH & $(5,18)$ & 1.78 & 0.170 \\
\hline
\end{tabular}

\subsection{Responses to Growth}

Overall, exposure to different concentrations of 2,4-D caused a decrease in average growth in the heights of Rhizophora mangle seedlings, in the 12- and 16-day periods where they were significantly lower $(20.2 \pm 0.8$ and $20.6 \pm 1.2 \mathrm{~cm}$, respectively) compared to the control group (21.7 \pm 0.6 and $23.3 \pm 1.3 \mathrm{~cm}$, respectively) (Figure 4A). Likewise, a diametrical increase in the treated plants at 12 and 16 days was significantly lower $(4.3 \pm 0.5$ and $5.4 \pm 0.4 \mathrm{~cm}$, respectively) compared to the control group $(5.7 \pm 0.4$ and $5.9 \pm 0.4 \mathrm{~cm}$, respectively) (Figure $4 \mathrm{~B}$ ).

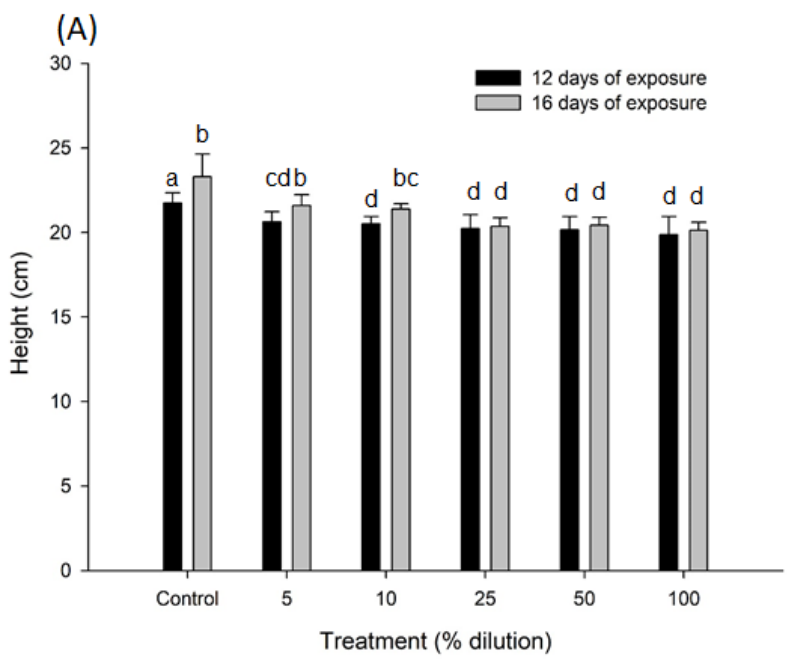

(B)

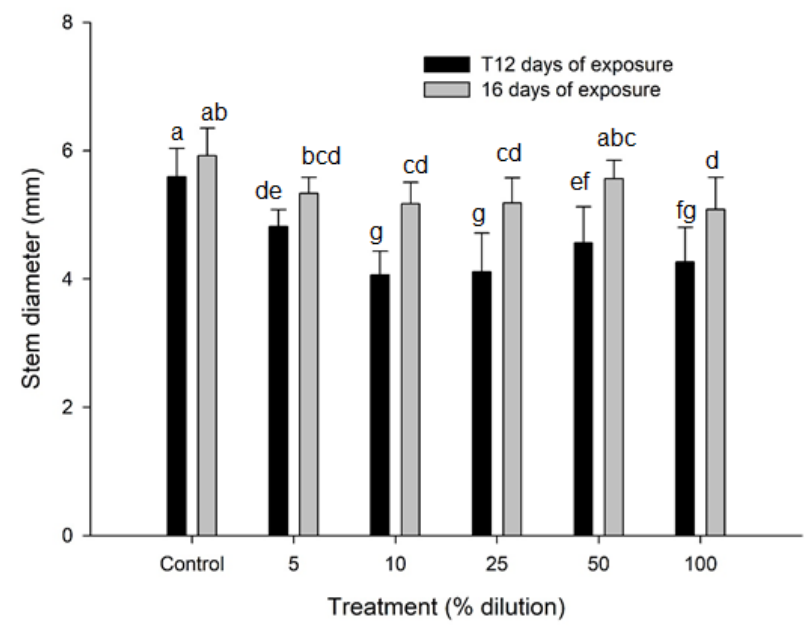

Figure 4. Average growth in (A) height; (B) stem diameter of Rhizophora mangle seedlings between treatments and exposure times. The error bars represent the standard deviation. Treatments that do not share a letter are significantly different $(p \leq 0.05)$. 
The effect of growth on height was noticeable from exposures of $25 \%$ to $100 \%$ of 2,4-D acid concerning control (Figure 4A), and diametrical stem growth was measured for exposure of $10 \%$ to $100 \%$ of 2,4 -D concerning control (Figure $4 \mathrm{~B}$ ).

When performing a two-way ANOVA, significant differences were observed in growth in terms of height and diameter (Table 3) between treatments and exposure times with 2,4-D acid.

Table 3. Two-way ANOVA concerning growth in height, diameter, and concentration of chlorophyll in Rhizophora mangrove seedlings between treatments (control, $5 \%, 10 \%, 25 \%, 50 \%$, and $100 \%$ ) and exposure times (12 and 16 days) with a significance level of $p<0.05$.

\begin{tabular}{ccccc}
\hline Parameter & Factor & G1 & F & $p$ \\
\hline \multirow{3}{*}{ Height $\mathbf{( c m )}$} & Treatment & 5 & 26.24 & $<0.001$ \\
& Time & 1 & 20.36 & $<0.001$ \\
& Treatment xTime & 5 & 2.46 & $<0.030$ \\
& Error & 90 & & \\
\hline \multirow{3}{*}{ Stem Diameter $(\mathbf{m m})$} & Treatment & 5 & 17.07 & $<0.001$ \\
& Time & 1 & 74.12 & $<0.001$ \\
& Treatment xTime & 5 & 2.36 & $<0.046$ \\
& Error & 90 & & $<0.001$ \\
Chlorophyll $\boldsymbol{a} \mathbf{( \mu g / g )}$ & Treatment & 5 & 471.65 & $<0.001$ \\
& Time & 1 & 431.84 & $<0.001$ \\
& Treatment xTime & 5 & 27.48 & \\
\hline
\end{tabular}

\subsection{Behavior of the Concentration of Chlorophyll a}

In general, the average concentration of photosynthetic pigment (chlorophyll $a$ ) of plants treated with 2,4-D acid, for the exposure times of 12 and 16 days, was significantly lower ( $60 \pm 18.5$ and $28 \pm 10.1 \mu \mathrm{g} / \mathrm{g}$, respectively) compared to the control group $(120 \pm 10.1$ and $121 \pm 10.7 \mu \mathrm{g} / \mathrm{g}$, respectively) (Figure 5).

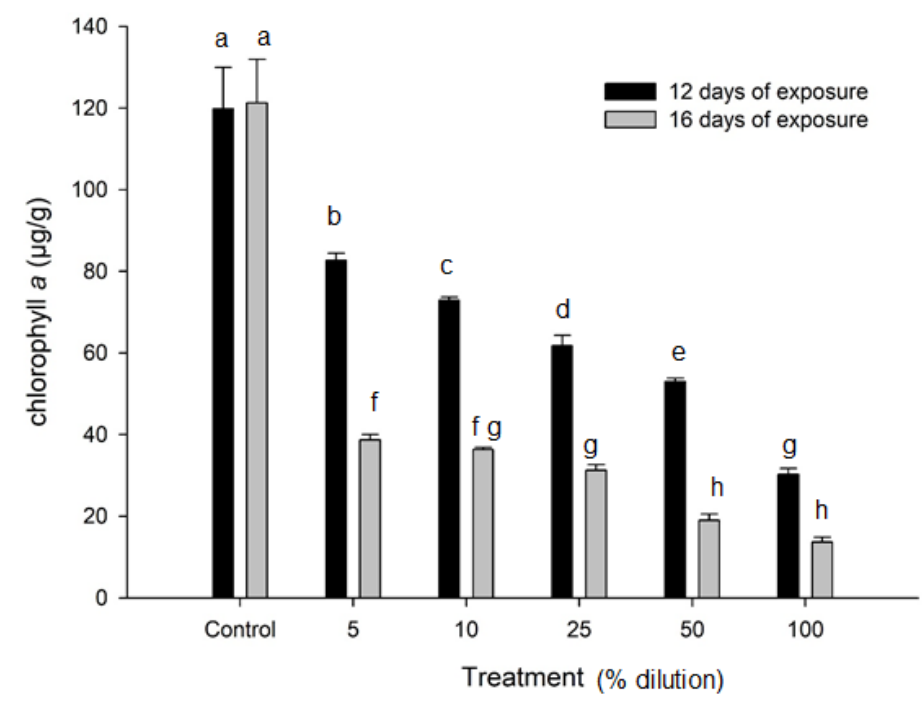

Figure 5. The average concentration of chlorophyll $a$ from Rhizophora mangle seedlings between treatments and exposure times. The error bars represent the standard deviation. Treatments that do not share a letter are significantly different $(p \leq 0.05)$.

The effect on chlorophyll $a$ concentration was observed from exposures of 2,4-D acid of $5 \%$ to $100 \%$ concerning the control in 12- and 16-day periods (Figure 5). 
When performing a two-way ANOVA, significant differences were observed between treatments and exposure times with 2,4-D acid in the concentration of chlorophyll $a$ in Rhizophora mangrove seedlings (Table 3).

Simple linear regression analysis established an inverse relationship between 2,4-D concentrations and chlorophyll concentrations $\left(Y=58.72-0.3883 X, R^{2}=0.96, p \leq 0.003\right)$.

\subsection{Biomass Production}

Seedlings exposed with 2,4-D acid treatments showed a decrease in biomass production by $26 \%$ in leaves and stems, $45 \%$ in root, and $35 \%$ in total biomass production relative to the control (Figure 6B, Figure 6A, and Figure 6C, respectively).

An effect on biomass production of Rhizophora mangrove seedlings was observed from exposures of $5 \%$ to $100 \%$ of 2,4-D acid relative to control (Figure $6 \mathrm{~A}-\mathrm{C}$ ). Likewise, the effect was very evident in the production of root biomass (Figure 6A).

(A)

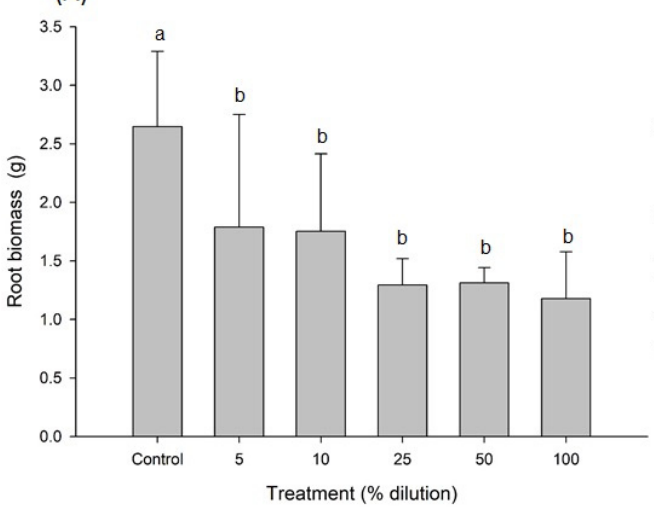

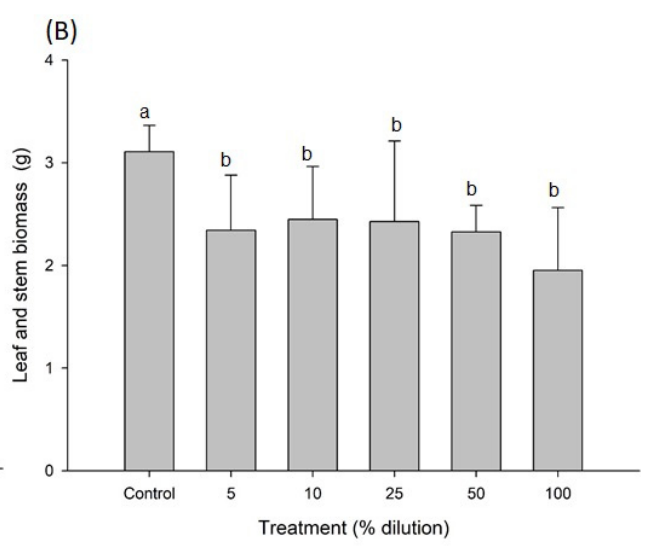

(c)

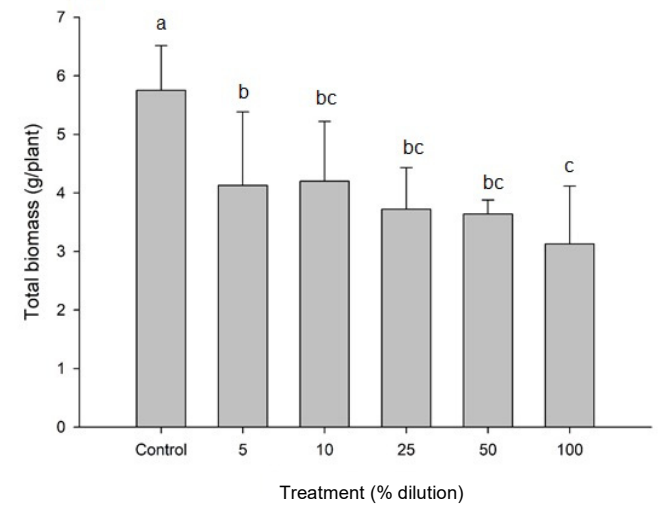

Figure 6. Average biomass production in (A) root and (B) leaves and stems, and (C) total biomass of Rhizophora mangle seedlings between treatments. The error bars represent the standard deviation. Treatments that do not share a letter are significantly different $(p<0.05)$.

Simple linear regression analysis established an inverse relationship between concentrations of 2,4-D and the production of total biomass of $R$. mangrove seedlings $(\mathrm{Y}=4.17-$ $0.0107 \mathrm{X}, \mathrm{R}^{2}=0.93, p \leq 0.008$ ).

Performing a one-way ANOVA analysis detected significant differences in the biomass production of treatments and control group seedlings (Table 4, Figure 6). 
Table 4. ANOVA of a pathway of the parameters of biomass of root, leaves, and stems, and total biomass of the seedlings of Rhizophora mangle in the ponds with treatments at the end of the experiment, with a significance level of $p<0.05$.

\begin{tabular}{cccc}
\hline Parameters & gl (Factor, Error) & Statistic F & $p$ Value \\
\hline Root Biomass (g) & $(5,30)$ & 5.34 & $<0.001$ \\
Leaf and Stem Biomass (g) & $(5,30)$ & 3.03 & $<0.025$ \\
Total Biomass (g/plant) & $(5,30)$ & 6.17 & $<0.001$ \\
\hline
\end{tabular}

\section{Discussion}

The controlled conditions carried out for this bioassay, as well as the emulation of the local tidal regime, favored obtaining better results. We considered that exposure concentrations of 2,4-D are constant through time experiments, and we could attribute adverse effects observed on propagules to pesticides; other variables of experiment associated with such effects on propagules were not found. According to the literature, 2,4-D is highly soluble in water and some forms of 2,4-D under certain conditions can persist for ten to hundreds of days before disintegrating; furthermore, it has been described that the ester forms of 2,4-D penetrate foliage, while the salt form of 2,4-D can be absorbed by the roots of plants. The ester forms are converted into acid within the plant and then accumulate in cells due to passive diffusion in the concentration gradient [42].

The physicochemical parameters of the interstitial water $\mathrm{pH}$, salinity, and temperature) during the experimental development did not show significant differences $(p>0.05)$ between the different treatments concerning the control, although not so for the redox potential, where significant differences were observed $(p<0.05)$. The various values of the redox potential of the experiment presented an oxic-type trend. Likewise, the values of variation in the redox potential between treatments can be due to the discharge from the 2,4-D solution at different concentrations during the process of recirculation and emulation of the tides, as well as the physicochemical reaction of mangrove sediment in ponds. In this regard, refs. [43,44] mention that the conditions of oxide reduction are related to hydrology (time of residence of water, frequency of flooding due to the effect of tides, and contributions of urban and/or industrial wastewater), as well as the contributions of organic matter in mangrove forests where changes in the redox potential are established. Moreover, the authors of [34], experimenting on the removal of nutrients from urban wastewater under controlled conditions similar to this study, mention that the exposed conditions of controlled simulation favored the results of the bioassay due to the tidal emulation of the local regime and the ideal survival conditions of the Rhizophora mangle species.

In general terms, the growth in diameter and stem of the seedlings of Rhizophora mangle showed a decrease in the control because of the bioavailability 2,4-D in the interstitial water at different concentrations which is absorbed by the roots. In this regard, the authors of [45] mention that one of the effects of herbicides in mangroves is a direct interference with the division and differentiation of cell development. The author of [46] also determined that contamination with 2,4-D in Rhizophora stylosa communities significantly inhibited seedling development due to cell degeneration and they described that persistence of herbicide residues in soil could inhibit the establishment and colonization of new mangrove seedlings.

The effects on the decrease in chlorophyll production in the leaves of seedlings treated with 2,4-D for the two exposure times are related to changes in physiological processes, such as photosynthesis and stress, due to the absorption of the herbicide, affecting the pigmentation system of seedlings, inhibition of photosynthetic efficiency, and stages of seedling development [47-49]. Similar findings have been reported by other authors [50,51], who describe the phytotoxic effect of 2,4-D on tobacco seedling leaves and the decrease in chlorophyll $a$ concentration as being due to cell degeneration and degradation of the chlorophyll molecule. Refs. [47,52] describe in a general way that mangroves are prone to natural or anthropogenic disturbances (stressed mangroves) where they experience 
decreases in foliar chlorophyll concentration and leaf litter production. On the other hand, an inverse relationship was determined $\left(R^{2}=0.96, p \leq 0.003\right)$ between the concentrations of 2,4-D and the concentration of chlorophyll $a$ in the leaves of seedlings of Rhizophora mangle, and similar results have been reported in [10] where a high negative correlation $\left(R^{2}=0.99, p \leq 0.005\right)$ between the concentration of the herbicide (diuron) in the sediment and concentration of chlorophyll $a$ in the leaves of Avicennia marina trees was determined, demonstrating the negative effect of herbicides on mangrove health in the Mackay region, located in Northeastern Australia.

With regard to biomass production, we believe that the decrease in biomass production in the roots, leaves, and stems of R. mangrove seedlings for treatments exposed to 2,4-D is due to the absorption and assimilation of bioavailable 2,4-D herbicide in the interstitial water of the treated ponds. Likewise, there was a greater inhibitory effect in the production of root biomass in seedlings, as the concentration of 2,4-D increased, with a decrease of $45 \%$ in root biomass relative to the control, specifically the greatest inhibitory effect was observed for the concentration at $100 \%$. In this regard, the authors of [53] mentioned that absorption through roots is the main route for the transfer of herbicides, where the influx of salts into mangroves is also regulated; that is, the morphology, anatomy, and biomass production of the roots is also associated with the absorption effect of herbicides, as presented in this study. Likewise, ref. [54] notes that the cumulative effect during the exposure of herbicides to the roots and leaves of seedlings of Avicennia corniculatum is due to physiological stress making it more sensitive. On the other hand, an inverse relationship was determined between the concentration of 2,4-D and the production of total biomass in the seedlings of Rhizophora mangle $\left(R^{2}=0.93, p \leq 0.008\right)$, which may be due to the decrease in photosynthetic efficiency and the lower production of chlorophyll $a$; therefore, affecting the production of the total biomass observed in this study. Reference [55] mentions that the photosynthetic rate in mangroves depends on the concentration of photosynthetic pigments, such as chlorophyll. Likewise, ref. [55] determined a positive correlation between the rate of carbon capture and the concentrations of chlorophyll $a$, chlorophyll $b$, and total chlorophyll in mangrove trees. The results of this bioassay were associated with the simulated conditions of hydrology; however, under natural conditions (environment), the factors that can influence the dispersion of 2,4-D are tidal frequency, type of soil in mangrove forests, and the dilution rate of 2,4-D. Moreover, this research demonstrated the adverse effects of 2,4-D on $R$. mangle seedlings. The reason why is considered fundamental and the priority of regulation of this herbicide for rational use, or even its prohibition, results in a recommending of it being replaced by bioherbicides. The latter are friendlier to the environment and the health of humans. Likewise, the acceptance and application of small, medium, and large-scale bioherbicides could define an effective strategy for the conservation and recovery of the health of ecosystems and the ecosystem services they provide.

\section{Conclusions}

This study describes the phytotoxic effect of 2,4-D on Rhizophora mangle seedlings, where phytotoxicity was related to adverse effects on the growth, diameter, stem, chlorophyll concentrations, and biomass production of leaves, stems, and roots. Likewise, all the concentrations of 2,4-D used in this experiment generated inhibitory effects in the production of chlorophyll and root biomass of the seedlings that were exposed. The toxic and physicochemical conditions presented during the development of the bioassay were generally those established in the normal tidal regimes, which favored the obtaining of better results for this study in contrast to experiments in which the tides were not emulated. Based on the results obtained in this study, we could describe that pollution from wastewater discharge containing heavy metals or herbicides and poor agricultural practices are worrying situations, since 2,4-D can affect the degree of health and permanence of mangroves, because at concentrations of $5 \%$ under experimental conditions, they can alter the morphophysiological functions of mangroves and affect the environmental services 
they provide. We consider that other studies can be carried out on the phytotoxic effects of other herbicides in common use, employing other species and numbers of individuals for areas impacted by afforestation, as well as the concentration of the herbicide to be applied.

Author Contributions: C.M.A.-H. and C.A.C.-K. conceived of the study, participated in its design and coordination, and helped to draft the manuscript. J.O.-S. and R.M.-S. advised during the study and analyzed and interpreted data. C.M.A.-H., R.M.-S., J.O.-S., R.A.P.-B., J.E.R.-C., E.J.G.-A. and C.A.C.-K. collected, analyzed, and interpreted the data. All authors have read and approved the final version of the manuscript.

Funding: This research received no external funding.

Data Availability Statement: Data is contained within the article.

Acknowledgments: The authors acknowledge the EPOMEX Institute of the Autonomous University of Campeche. We also thank Gerardo Martinez and Gilberto Martinez Muñoz for their help during the monitoring period.

Conflicts of Interest: The authors declare no competing interests.

\section{References}

1. Turner, B.L.; Kasperson, R.E.; Matson, P.A.; McCarthy, J.J.; Corell, R.W.; Christensen, L.; Eckley, N.; Kasperson, J.X.; Luers, A.; Martello, M.L.; et al. A framework for vulnerability analysis in sustainability science. Proc. Natl. Acad. Sci. USA 2003, 100, 8074-8079. [CrossRef] [PubMed]

2. Mazda, Y.; Magi, M.; Kogo, M.; Hong, P.N. Mangroves as a coastal protection from waves in the Tong King delta, Vietnam. Mangroves Salt Marshes 1997, 1, 127-135. [CrossRef]

3. Barbier, E.B. Ecosystems as Natural Assets. Found. Trends Microecon. 2008, 4, 611-681. [CrossRef]

4. Alongi, D.; Sasekumar, A.; Chong, V.; Pfitzner, J.; Trott, L.; Tirendi, F.; Dixon, P.; Brunskill, G. Sediment accumulation and organic material flux in a managed mangrove ecosystem: Estimates of land-ocean-atmosphere exchange in peninsular Malaysia. Mar. Geol. 2004, 208, 383-402. [CrossRef]

5. Agraz-Hernández, C.; Chan-Keb, C.; Muñiz-Salazar, R.; Pérez-Balan, R.; Osti-Sáenz, J.; Gutiérrez-Alcántara, E.; Reyes-Castellano, J.; May-Colli, L.; Conde-Medina, K.; Ruiz-Hernández, J. Relationship between blue carbon and methane and the hydrochemistry of mangroves in southeast Mexico. Appl. Ecol. Environ. Res. 2020, 18, 1091-1106. [CrossRef]

6. Giri, C.; Ochieng, E.; Tieszen, L.L.; Zhu, Z.; Singh, A.; Loveland, T.; Masek, J.; Duke, N. Status and distribution of mangrove forests of the world using earth observation satellite data. Glob. Ecol. Biogeogr. 2011, 20, 154-159. [CrossRef]

7. Alongi, D.M. Present state and future of the world's mangrove forests. Environ. Conserv. 2002, 29, 331-349. [CrossRef]

8. Zheng, G.J.; Lam, M.H.; Lam, P.K.; Richardson, B.J.; Man, B.K.; Li, A.M. Concentrations of Persistent Organic Pollutants in Surface Sediments of the Mudflat and Mangroves at Mai Po Marshes Nature Reserve, Hong Kong. Mar. Pollut. Bull. 2000, 40, $1210-1214$. [CrossRef]

9. Peters, E.C.; Gassman, N.J.; Firman, J.C.; Richmond, R.H.; Power, E.A. Ecotoxicology of tropical marine ecosystems. Environ. Toxicol. Chem. 1997, 16, 12-40. [CrossRef]

10. Duke, N.C.; Bell, A.M.; Pederson, D.K.; Roelfsema, C.; Nash, S.B. Herbicides implicated as the cause of severe mangrove dieback in the Mackay region, NE Australia: Consequences for marine plant habitats of the GBR World Heritage Area. Mar. Pollut. Bull. 2005, 51, 308-324. [CrossRef]

11. Lee, S.Y. Tropical mangrove ecology: Physical and biotic factors influencing ecosystem structure and function. Austral Ecol. 1999, 24, 355-366. [CrossRef]

12. Nath, B.; Birch, G.; Chaudhuri, P. Trace metal biogeochemistry in mangrove ecosystems: A comparative assessment of acidified (by acid sulfate soils) and non-acidified sites. Sci. Total. Environ. 2013, 463-464, 667-674. [CrossRef]

13. Rai, P.K. Heavy Metal Pollution in Aquatic Ecosystems and its Phytoremediation using Wetland Plants: An ecosustainable approach. Int. J. Phytoremediation 2008, 10, 133-160. [CrossRef]

14. Sánchez Páez, H.; Ulloa Delgado, G.A.; Alvarez León, R.; Gil Torres, W.O. Colombia. In Ministerio del Medio Ambiente; Asociación Colombiana de Reforestadores.; Organización Internacional de las Maderas Tropica-les. Hacia la recuperación de los Manglares del Caribe Colombiano; de Bogotá, S., Ed.; Ministerio del Medio Ambiente: Bogotá, Colombia, 2000; ISBN 9583316849.

15. Cuong, D.T.; Bayen, S.; Wurl, O.; Subramanian, K.; Wong, K.K.S.; Sivasothi, N.; Obbard, J.P. Heavy metal contamination in mangrove habitats of Singapore. Mar. Pollut. Bull. 2005, 50, 1732-1738. [CrossRef]

16. Dietz, K.J.; Baier, M.; Krämer, U. Free radicals and reactive oxygen species as mediators of heavy metal toxicity in plants. In Heavy Metal Stress in Plants; Springer: Berlin/Heidelberg, Germany, 1999; pp. 73-97.

17. Ivens, G.W. Arboricides for killing mangroves. In West African Rice Research Station Periodical Science Report, 8; West Africa Rice Development association, WARDA-ADRAO: ABIDJAN 01, Cote d' Ivoire, 1957.

18. Teas, H.J. Herbicide Toxicity in Mangroves; EPA-600/3-76-004; National Technical Information Service: Springfield City, FL, USA, 1976. 
19. Peng, L.; Wenjian, Z.; Zhenji, L. Distribution and accumulation of heavy metals in Avicennia marina community in Shenzhen. China. J. Environ. Sci. 1997, 9, 472-479.

20. MacFarlane, G. Leaf biochemical parameters in Avicennia marina (Forsk.) Vierh as potential biomarkers of heavy metal stress in estuarine ecosystems. Mar. Pollut. Bull. 2002, 44, 244-256. [CrossRef]

21. Rivera-Arriaga, E.; Williams-Beck, L.; Hernández, L.E.V.; Arjona, M.E.G. Crafting grassroots' socio-environmental governance for a coastal biosphere rural community in Campeche, Mexico. Ocean Coast. Manag. 2021, 204, 105518. [CrossRef]

22. CONANP (Comisión Nacional de Áreas Naturales Protegidas). Programa de Conservación y Manejo RESERVA de la BIOSFERA los Petenes; CONANP: Mexico City, México, 2006.

23. Armitage, D.; Alexander, S.; Andrachuk, M.; Berdej, S.; Brown, S.; Nayak, P.; Pittman, J.; Rathwell, K. Communities, multi-level networks and governance transformations in the coastal commons. Gov. Coast. Commons 2017, 231-251. [CrossRef]

24. Bautista, F.; Palacio, A.G. Caracterización y Manejo de los Suelos de la Península de Yucatán: Implicaciones Agropecuarias, Forestales y Ambientales, 1st ed.; Instituto Nacional de Ecología: Mexico City, Mexico, 2005.

25. Bautista, F.; Palacio, A.; Mendoza, J.; Kú, V.; Pool, L.; Cantarell, W. Suelos. In La Biodiversidad en Campeche: Estudio de Estado; Villalobos-Zapata, G.J., Mendoza-Vega, J., Eds.; Comisión Nacional Para el Conocimiento y Uso de la Biodiversidad (CONABIO): Tlalpan, Mexico, 2010; p. 748, ISBN 978-607-7887-22-5.

26. Troche-Souza, C.; Rodríguez-Zúñiga, M.T.; Velázquez-Salazar, S.; Valderrama-Landeros, L.; Villeda-Chavéz, E.; Alcántara-Maya, A.; Vázquez-Balderas, B.; Cruz-López, M.I.; Ressl, R. Manglares de México: Extensión, Distribución y Monitoreo (1970/1980-2015), 1st ed.; Comisión Nacional Para el Conocimiento y Uso de la Biodiversidad.: Ciudad de México, Mexico, 2017; ISBN 978-607-8328-78-9.

27. Velázquez-Salazar, S.; Rodríguez-Zúñiga, M.; Alcántara-Maya, J.; Villeda-Chávez, E.; Valderra-ma-Landeros, L.; Troche-Souza, C.; Vázquez-Balderas, B.; Pérez-Espinosa, I.; Cruz-López, M.I.; Ressl, R.; et al. Manglares de México. Actualización y Análisis de los Datos 2020, 1st ed.; Comisión Nacional Para el Conocimiento y Uso de la Biodiversidad: Tlalpan, México, 2021; ISBN 9786078570508.

28. Naidoo, G. The mangroves of South Africa: An ecophysiological review. S. Afr. J. Bot. 2016, 107, 101-113. [CrossRef]

29. Chan-Keb, C.A.; Agraz-Hernández, C.M.; Perez-Balan, R.A.; Gómez-Solano, M.I.; Maldonado-Montiel, T.D.; Ake-Canche, B.; Gutiérrez-Alcántara, E.J. Acute toxicity of water and aqueous extract of soils from Champotón river in Lactuca sativa L. Toxicol. Rep. 2018, 5, 593-597. [CrossRef]

30. Yanes, C.V.; Irene, A.; Muñoz, B.; Isabel, M.; Silva, A.; Gual Díaz, M.; Cristina, Y.; Dirzo, S. Árboles Mexicanos Potencialmente Valiosos Para la Restauración Ecológica y la Reforestación; Bases de datos SNIB-CONABIO, proyecto J084; Comisión Nacional Para el Conocimiento y uso de la Biodiversidad: Tlalpan, Mexico, 1999.

31. Gill, A.M.; Tomlinson, P.B. Studies on the Growth of Red Mangrove (Rhizophora mangle L.) 4. The Adult Root System. Biotropica 1977, 9, 145. [CrossRef]

32. Maricusa Agraz Hernández, C.; Armando, C.; Keb, C.; Iriarte-Vivar, S.; Venegas, G.P.; Serratos, B.V.; Osti Sáenz, J.; Hernández, A.; Keb, C.A.C.; Iriarte-Vivar, S.I.; et al. Phenological variation of Rhizophora mangle and ground water chemistry associated to changes of the precipitation. Hidrobiológica 2015, 25, 49-61.

33. Cissell, J.R.; Delgado, A.M.; Sweetman, B.M.; Steinberg, M.K. Monitoring mangrove forest dynamics in Campeche, Mexico, using Landsat satellite data. Remote. Sens. Appl. Soc. Environ. 2018, 9, 60-68. [CrossRef]

34. Agraz-Hernández, C.M.; Del Río-Rodríguez, R.E.; Chan-Keb, C.A.; Osti-Sáenz, J.; Muñiz-Salazar, R. Nutrient Removal Efficiency of Rhizophora mangle (L.) Seedlings Exposed to Experimental Dumping of Municipal Waters. Diversity 2018, 10, 16. [CrossRef]

35. Skoog, D.A.; West, D.M.; Holler, F.J.; Crouch, S.R. Fundamentals of Analytical Chemistry; Cengage Learning Group, Inc.: Independence, KY, USA, 2013; ISBN 9780495558286.

36. Gervais, J.; Luukinen, B.; Buhl, K.; Stone, D. 2,4-D Technical Fact, National Pesticide Information Center, Oregon State University Extension Services. Available online: http:/ / npic.orst.edu/factsheets/archive/2,4-DTech.html (accessed on 18 November 2021).

37. Duke, N.C.; Zuleika, S.; Pinzon, M. Aging Rhizophora Seedlings from Leaf Scar Nodes: A Technique for Studying Recruitment and Growth in Mangrove Forests. Biotropica 1992, 24, 173. [CrossRef]

38. Hernández, C.M.A.; Zaragoza, C.G.; Iriarte-Vivar, S.; Flores-Verdugo, F.J.; Casasola, P.M. Forest structure, productivity and species phenology of mangroves in the La Mancha lagoon in the Atlantic coast of Mexico. Wetl. Ecol. Manag. 2011, 19, 273-293. [CrossRef]

39. Strickland, J.D.H.; Parsons, T.R. A Manual of Seawater Analysis; Fisheries Research Board of Canada: Ottawa, ON, Canada, 1965; Volume 125.

40. Shapiro, S.S.; Wilk, M.B. An Analysis of Variance Test for Normality (Complete Samples). Biometrika 1965, 52, 591. [CrossRef]

41. Zar, J.H. Biostatistical Analysis, 5th ed.; Pearson Prentice Hall: Upper Saddle River, NJ, USA, 2010; ISBN 9780131008465.

42. NPIC 2,4-D Technical Fact Sheet. Available online: http:/ / npic.orst.edu/factsheets/24Dgen.html (accessed on 16 November 2021).

43. Mitsch, W.J.; Gosselink, J. Wetlands, 3rd ed.; John Wiley \& Sons: New York, NY, USA, 2000.

44. Gleason, S.; Ewel, K.; Hue, N. Soil redox conditions and plant-soil relationships in a micronesian mangrove forest. Estuar. Coast. Shelf Sci. 2003, 56, 1065-1074. [CrossRef]

45. Ashton, F.M.; Crafts, A.S. Mode of Action of Herbicides, 1st ed.; Wiley-Interscience: New York, NY, USA, 1973.

46. Culic, P. The effects of 2,4-D on the growth of Rhizophora stylosa Griff. seedlings. In Physiology and Management of Mangroves, Tasks for Vegetation Science; Teas, H.J., Ed.; Springer: Dordrecht, The Netherlands, 1984. 
47. Filella, I.; Penuelas, J. The red edge position and shape as indicators of plant chlorophyll content, biomass and hydric status. Int. J. Remote. Sens. 1994, 15, 1459-1470. [CrossRef]

48. Haboudane, D.; Miller, J.R.; Tremblay, N.; Zarco-Tejada, P.J.; Dextraze, L. Integrated narrow-band vegetation indices for prediction of crop chlorophyll content for application to precision agriculture. Remote. Sens. Environ. 2002, 81, 416-426. [CrossRef]

49. Wu, C.; Niu, Z.; Tang, Q.; Huang, W. Estimating chlorophyll content from hyperspectral vegetation indices: Modeling and validation. Agric. For. Meteorol. 2008, 148, 1230-1241. [CrossRef]

50. Hallam, N.D. The Effect of 2,4-Dichlorophenoxyacetic Acid and Related Compounds on the Fine Structure of the Primary Leaves of Phaseolus vulgaris. J. Exp. Bot. 1970, 21, 1031-1038. [CrossRef]

51. White, J.A.; Hemphill, D.D. An Ultrastructural Study of the Effects of 2,4-D on Tobacco Leaves. Weed Sci. 1972, 20, 478-481. [CrossRef]

52. Flores-De-Santiago, F.; Kovacs, J.M.; Flores-Verdugo, F. The influence of seasonality in estimating mangrove leaf chlorophyll-a content from hyperspectral data. Wetl. Ecol. Manag. 2013, 21, 193-207. [CrossRef]

53. Chambers, A.J.; Victoria, A. Field Crop Herbicide Guide 1997-1998: Detailed Information on Australian Field Crop Herbicides 1997-98., 5th ed.; Kondinin Group: Perth, WA, Australia, 1997.

54. Bell, A.M.; Duke, N.C. Effects of Photosystem II inhibiting herbicides on mangroves-Preliminary toxicology trials. Mar. Pollut. Bull. 2005, 51, 297-307. [CrossRef]

55. Moorthy, P.; Kathiresan, K. Influence of ultraviolet- $\beta$ radiation on photosynthetic and biochemical characteristics of a mangrove Rhizophora apiculata. Photosynthetica 1997, 34, 465-471. [CrossRef] 